\title{
Maintenance of weight loss in obese patients after jaw wiring
}

\author{
J S GARROW, G T GARDINER
}

\begin{abstract}
In treatment of obesity restriction of food intake is necessary to achieve good results. Various operations have been devised to prevent patients overeating, but in this study jaw wiring was used to limit food intake. This procedure produces weight loss in obese patients but when the wires are removed the weight is usually regained. This report studied a group of patients whose weight loss was maintained after the wires were removed. A nylon cord fastened round the waist of the patient after weight reduction was found to act as a psychological barrier to weight gain. Seven patients were followed for 4-14 months after removal of jaw wires and regained a mean of only $5.6 \mathrm{~kg}$ of the $31.8 \mathrm{~kg}$ lost while their jaws were wired.
\end{abstract}

This procedure compares favourably with other treatments for severe obesity.

\section{Introduction}

Severe obesity carries a high mortality and morbidity. ${ }^{12}$ To lose $40 \mathrm{~kg}$ of adipose tissue the obese patient must achieve an energy deficit of about $280 \mathrm{Mcal}(1200 \mathrm{MJ}) .^{3}$ This requires an intake about $1000 \mathrm{kcal}(4 \cdot 2 \mathrm{MJ})$ less than maintenance requirements every day for nine months. Few can achieve such selfdenial without help. Various operations have been devised to prevent such patients from overeating, either by reducing the capacity of the stomach ${ }^{4}$ or by inducing malabsorption by jejunoileal bypass. ${ }^{5}$ It is now clear that the weight loss after jejunoileal bypass is caused by decreased food intake and not directly by the malabsorption. ${ }^{6}$

Since obese patients are bad operative risks we have preferred to limit food intake by jaw wiring, ${ }^{7}$ which is much safer and less expensive. This procedure, however, has been condemned on the grounds that weight is almost inevitably regained when the wires are removed. ${ }^{8}$ For this reason we have followed jaw wiring by a gastric reduction procedure. ${ }^{\circ}$ We report here a small series of patients in whom weight loss was well maintained after release of jaw wiring without any surgical procedure: we found that a nylon cord fastened round the waist of the patient after weight reduction provided a psychological barrier to weight gain.

\section{Patients and methods}

All patients were referred to JG for treatment of obesity and underwent the inpatient investigations previously described..$^{10}$ These have been approved by the Northwick Park Hospital ethical committee. The decision to offer jaw wiring was limited to patients under the age of 50 years, who had a resting metabolic rate of over $240 \mathrm{ml} \mathrm{O} / \mathrm{min}$, an obesity index $\left(\mathbb{W} / \mathrm{H}^{2}\right)$ over 35 , and suitable dentition. A full explanation of the jaw wiring and (where applicable) waist cord procedure was given to the patients and their spouses, and patients

Nutrition Research Group, Clinical Research Centre, Harrow, Middlesex HA1 3UJ

J S GARROW, FRCP, consultant physician

Department of Oral Surgery, Mount Vernon Hospital, Northwood, Middlesex

G T GARDINER, FDSRCS, FRACDS, consultant oral surgeon had an opportunity to discuss the advantages and disadvantages with other patients who had had experience of the procedure. Written consent was then obtained from both patient and spouse.

Nine patients were treated for obesity by jaw wiring and were followed for at least 10 months after the wires were removed. These patients were part of a series already reported ${ }^{9}$ and were used as the control group.

In view of the poor long-term results of the control group, all patients qualifying for jaw wiring since April 1979 were offered a programme in which, after a period of jaw wiring to attain the necessary weight loss, a nylon cord was fixed round the waist to give warning of weight regain. Fourteen patients were offered this programme, and all accepted. This report concerns the seven patients who have been followed for 4-14 months since their jaws were unwired and the waist cord was fitted. Of the other seven patients, four still have their jaws wired, one has had a surgical operation which required removal of wires, and two have had a waist cord fitted for less than two months.

For the jaw wiring $0.5 \mathrm{~mm}$ stainless steel eyelet wires were placed around posterior teeth only. Intermaxillary fixation was effected by two tie wires on either side but varied to suit individual dentitions. This stainless steel is heavier than is usually used to immobilise fractures of the jaws. This is because the period of fixation is so much longer and because patients with intact jaws, unlike those with fractured jaws, can exert immediately strong bursting forces during yawning or sneezing.

Only local anaesthesia was used during the wiring procedure and no provision was made for releasing the wiring either to prevent stiffening of the temporomandibular joint ${ }^{11}$ or to enable the patient to clear the air passages in the event of vomiting, ${ }^{8}$ since we have not found this to be necessary. Patients were given diazepam, $20 \mathrm{mg}$ orally, immediately they returned to the ward after wiring; this prevented spasm of the masseter and enabled the patient to sleep while tenderness in the teeth and gums subsided.

After wiring, the patients were advised to take two pints $(1200 \mathrm{ml})$ of whole cows' milk daily as the sole energy source. This was supplemented with $200 \mathrm{mg}$ ferrous sulphate and one multivitamin capsule $B P C$ daily. Usually it was possible to pass the tablets, crushed if necessary, through a gap in the teeth. Acaloric fluids were allowed ad libitum, and patients were encouraged to maintain a high fluid intake. They were warned to avoid drinks containing sugar, since they would delay weight loss and predispose to bacterial growth in the mouth. Oral hygiene was maintained by brushing the outer aspect of the teeth and by using a mouthwash. Patients were seen monthly during the jaw wiring period to check, and if necessary repair, the jaw fixation and to monitor the progress of weight loss. When adequate weight loss had been achieved (usually after 6-12 months) an appointment was made for the patient to come into hospital for repeat measurement of metabolic rate and body composition, for removal of the jaw wires, and (where applicable) for fitting of the waist cord.

Initially cord $5 \mathrm{~mm}$ in diameter was used for the waist cord, but this was too bulky and showed through light clothing, so $2 \mathrm{~mm}$ cord was subsequently used. It was applied with the patient supine and tied at a circumference of about $700 \mathrm{~mm}$. The next day it was checked for tightness: ideally it had to produce no indentation of the skin with the patient supine but make a white (not red) line on the skin when the patient was seated. The length of the cord was adjusted until this tension was achieved, and the knot was then sealed by melting the ends of the cord gently, taking care not to burn the patient.

\section{Results}

The weight change during the period of jaw wiring, and after the wires were removed, is shown in table $I$ for the group who were fitted with a waist cord and in table II for the control group. The two groups did not differ significantly in initial weight, height, or age. The control group had their jaws wired for a slightly shorter period and lost slightly less weight, but the rate of weight loss of the two groups was similar. 
The striking difference between the two groups was in the weight change after the wires were removed. In the control group the average rate of weight gain was $1.8 \mathrm{~kg} /$ month, but in the group with waist cords there was no significant weight gain after the initial increase, which occurred within two months of removal of the wires (figure). By five months after unwiring the waist cord group had gained significantly less weight than the control group $(p<0.05)$ and the average difference between the groups thereafter steadily increased.

No patients dropped out of treatment in either group. secondly, those fitted with a waist cord showed an initial weight gain when the wires were removed but then stabilised at a weight about $6 \mathrm{~kg}$ above their minimum weight.

The absence of dropouts from treatment is probably explained by our selection procedure. Patients have ample opportunity to withdraw from the jaw wiring programme during the preliminary tests; if they do proceed they have an accurate idea of the disadvantages and of the rate of weight loss that they can expect. Furthermore, once the wires have been applied they are

TABLE I-Weight change in seven obese women during and after jaw wiring followed by fitting of a waist cord

\begin{tabular}{|c|c|c|c|c|c|c|c|}
\hline $\begin{array}{l}\text { Case } \\
\text { No }\end{array}$ & $\begin{array}{c}\text { Initial } \\
\text { weight } \\
(\mathbf{k g})\end{array}$ & $\begin{array}{l}\text { Height } \\
\text { (m) }\end{array}$ & $\underset{\text { (years) }}{\text { Age }}$ & $\begin{array}{l}\text { Duration } \\
\text { of wiring } \\
\text { (months) }\end{array}$ & $\begin{array}{l}\text { Weight loss } \\
\text { during jaw } \\
\text { wiring (kg) }\end{array}$ & $\begin{array}{l}\text { Follow-up } \\
\text { since wires } \\
\text { off (months) }\end{array}$ & $\begin{array}{l}\text { Weight gain } \\
\text { since wires } \\
\text { off }(\mathbf{k g})\end{array}$ \\
\hline $\begin{array}{l}1 \\
2 \\
3 \\
4 \\
5 \\
6 \\
7\end{array}$ & $\begin{array}{r}126 \\
120 \\
90 \\
95 \\
103 \\
116 \\
105\end{array}$ & $\begin{array}{l}1.66 \\
1.65 \\
1.56 \\
1.66 \\
1.66 \\
1.53 \\
1.58\end{array}$ & $\begin{array}{l}19 \\
22 \\
33 \\
33 \\
29 \\
42 \\
34\end{array}$ & $\begin{array}{r}17 \\
7 \\
6 \\
11 \\
6 \\
11 \\
7\end{array}$ & $\begin{array}{l}53 \\
44 \\
36 \\
22 \\
39 \\
36 \\
37\end{array}$ & $\begin{array}{r}14 \\
9 \\
8 \\
8 \\
7 \\
5 \\
4\end{array}$ & $\begin{array}{l}6 \\
5 \\
6 \\
9 \\
5 \\
6 \\
2\end{array}$ \\
\hline Mean: SD & $107: 13$ & $1.61: 0.06$ & $30 \div 8$ & $9 \cdot 3 \div 4.0$ & $38 \cdot 1 \pm 9.4$ & $7 \cdot 8+3 \cdot 2$ & $5 \cdot 6 \pm 2 \cdot 1$ \\
\hline
\end{tabular}

TABLE II-Weight change in nine obese women during and 10 months after jaw wiring without waist cord (control group)

\begin{tabular}{|c|c|c|c|c|c|c|}
\hline $\begin{array}{l}\text { Case } \\
\text { No }\end{array}$ & $\begin{array}{c}\text { Initial } \\
\text { weight } \\
\text { (kg) }\end{array}$ & $\underset{(\mathrm{m})}{\text { Height }}$ & $\begin{array}{c}\text { Age } \\
\text { (years) }\end{array}$ & $\begin{array}{l}\text { Duration } \\
\text { of wiring } \\
\text { (months) }\end{array}$ & $\begin{array}{l}\text { Weight loss } \\
\text { during jaw } \\
\text { wiring }(\mathbf{k g})\end{array}$ & $\begin{array}{l}\text { Weight gain in } \\
10 \text { months since } \\
\text { unwiring }(\mathrm{kg})\end{array}$ \\
\hline $\begin{array}{r}8 \\
9 \\
10 \\
11 \\
12 \\
13 \\
14 \\
15 \\
16\end{array}$ & $\begin{array}{l}123 \\
135 \\
109 \\
105 \\
115 \\
108 \\
115 \\
127 \\
101\end{array}$ & $\begin{array}{l}1.60 \\
1.68 \\
1.58 \\
1.67 \\
1.64 \\
1.67 \\
1.67 \\
1.58 \\
1.64\end{array}$ & $\begin{array}{l}43 \\
28 \\
22 \\
33 \\
40 \\
25 \\
34 \\
38 \\
33\end{array}$ & $\begin{array}{r}13 \\
5 \\
6 \\
8 \\
11 \\
8 \\
7 \\
7 \\
8\end{array}$ & $\begin{array}{l}52 \\
20 \\
28 \\
22 \\
28 \\
37 \\
25 \\
29 \\
32\end{array}$ & $\begin{array}{r}24 \\
19 \\
25 \\
7 \\
24 \\
20 \\
10 \\
17 \\
14\end{array}$ \\
\hline Mean : SD & $115: 11$ & $1.64: 0.04$ & $33: 7$ & $8 \cdot 1: 2.5$ & $30 \cdot 3 \pm 9 \cdot 6$ & $17 \cdot 8+6 \cdot 4$ \\
\hline
\end{tabular}

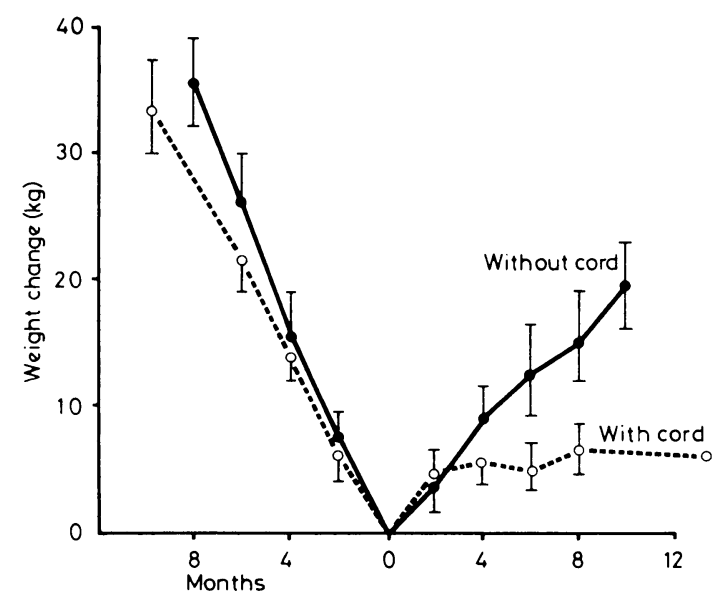

Weight change (mean + SEM) before and after jaw wiring in seven women fitted with a waist cord after the wires were removed (open circles) and in nine women who did not have a waist cord fitted (closed circles).

\section{Discussion}

The rate of weight loss in both these groups was similar to that reported by other workers in patients treated for obesity by jaw wiring. ${ }^{811-13}$ Our results differ from other reports in two respects: firstly, there were no dropouts from treatment, and, left in place until the necessary weight loss has been achieved. Programmes in which the wires are applied and removed every few weeks ${ }^{11} 14$ have a high dropout rate, since this is unsettling for the patient. Patients opt to have their jaws wired because they cannot stand the stress of deciding from day to day whether they can continue dieting; once their jaws are fixed they and their families accept the situation, just as hospital inpatients accept the situation. Just as weekend leave at home can upset a patient's ability to tolerate a reducing diet in hospital, so releasing and replacing jaw fixation may place an unnecessary strain on the patient. After nine months of continuous intermaxillary fixation patients are often unable immediately to open the jaws fully, but full movement returns in a few days. It certainly does not seem to be in the patient's interests to release fixation periodically to avoid so small a disability.

The limitation of weight gain to about $6 \mathrm{~kg}$ after unwiring of the jaws was clearly attributable to the waist cord, since this effect has not been reported in other series, nor was it seen in our control group. Patients who have lost a large amount of weight tend to be unduly optimistic that they will maintain this weight loss and are surprised and disappointed when they discover, on being weighed in outpatients, that they have gained several kilogrammes. It was noticeable that those patients who maintained weight loss (case 11, table II) were those who bought new clothes that fitted at their reduced weight and warned them when their weight increased. The waist cord performs a similar function. It is, of course, possible for patients to cut the cord, just as it is possible to cut the wires fixing the jaws, but patients 
are reluctant to take this step, which frustrates the attainment of an objective they themselves desire.

This small series is reported because we believe that jaw wiring followed by the fitting of a waist cord could be a valuable treatment for severe obesity. Unlike the bypass procedures it is inexpensive and safe. Only one of our patients (case 4, table I) seems unwilling to tolerate the waist cord: the others are maintaining their weight at a level just below that at which it is uncomfortable. Several patients have volunteered the observation that they would have gained weight on holiday had it not been for the waist cord, and they are anxious that it should not be removed. This result supports the hypothesis that such factors as the tightness of clothing are important in regulating body weight. ${ }^{15}$

\author{
References \\ 1 James WPT, ed. Research on obesity: a report of the DHSS/MRC study \\ group. London: HMSO, 1976:94. \\ 2 Bray GA, ed. Obesity in America. Bethesda Md.: US Department of \\ Health Education and Welfare, 1979. (NIH Publication No. 79-358). \\ ${ }^{3}$ Garrow JS. Energy balance and obesity in man. Amsterdam: Elsevier/ \\ North Holland, 1978.
}

${ }^{4}$ Mason EE, Printen KJ, Blommers TJ, Lewis JW, Scott DH. Gastric bypass in morbid obesity. Am $\mathcal{F}$ Clin Nutr $1980 ; 33: 395-405$.

5 O'Leary JP. Overview: Jejunoileal bypass in the treatment of morbid obesity. Am F Clin Nutr $1980 ; 33: 389-94$.

${ }^{6}$ Pilkington TRE, Gazet J-C, Ang L, Kalucy RS, Crisp AH, Day S. Explanation for weight loss after ileojejunal bypass in gross obesity. Br Med f 1976; : 1504-5.

7 Garrow JS. Dental splinting in the treatment of hyperphagic obesity. Proc Nutr Soc 1974;33:29A.

${ }^{8}$ Drenick EJ, Hargis HW. Jaw wiring for weight reduction. Obesity $\&$ Bariatric Medicine $1978 ; 7 \cdot 210-3$

${ }^{9}$ Fordyce GL, Garrow JS, Kark AE, Stalley SF. Jaw wiring and gastric bypass in the treatment of severe obesity. Obesity $\mathcal{E}$ Bariatric Medicine $.1979 ; 8: 14-7$.

10 Garrow JS, Durrant ML, Mann S, Stalley SF, Warwick P. Factors determining weight loss in obese patients in a metabolic ward. International fournal of Obesity, 1978;2:441-7.

11 Wood GD. Early results of treatment of the obese by a diet regimen enforced by maxillomandibular fixation. F Oral Surg 1977;35:461-4.

12 Rodgers S, Burnet R, Goss A, et al. Jaw wiring in the treatment of obesity Lancet $1977 ; \mathrm{i}: 1221-3$.

${ }^{13}$ Harding PE. Jaw wiring for obesity. Lancet 1980 ;i :534-5.

14 Castelnuovo-Tedesco P, Buchanan DC, Hall HD. Jaw wiring for obesity. General Hospital Psychiatry 1980 ;2:156-9.

15 Garrow JS, Stalley SF. Cognitive thresholds and human body weight. Proc Nutr Soc 1977;36:18A.

(Accepted 5 fanuary 1981)

\title{
Treatment of severe aplastic anaemia with antilymphocyte globulin or bone-marrow transplantation
}

\author{
BRUNO SPECK, ALOIS GRATWOHL, CATHERINE NISSEN, URS LEIBUNDGUT, \\ DONATELLA RUGGERO, BRUNO OSTERWALDER, HANS PETER BURRI, \\ PIERRE CORNU, MICHEL JEANNET
}

\begin{abstract}
Fifty-three patients with severe aplastic anaemia were admitted to this hospital between January 1976 and June 1980, of whom three arrived in terminal condition and died before treatment for their basic disease could be given. Thus 50 patients were treated and evaluated in a prospective study according to one protocol. Eighteen patients with an HLA-identical sibling underwent bonemarrow transplantation with the aim of achieving haematopoietic chimerism. Thirty-two patients without an HLA-identical sibling were given antilymphocyte globulin with or without an infusion of HLA-haplotypeidentical marrow. All these 32 patients received low-dose androgens after the procedure. In the first group eight
\end{abstract}

Division of Haematology, Department of Internal Medicine,

Kantonsspital, University of Basle, Switzerland

BRUNO SPECK, MD, professor of haematology

ALOIS GRATWOHL, MD, senior resident in haematology

CATHERINE NISSEN, MD, research fellow

URS LEIBUNDGUT, MD, research fellow

BRUNO OSTERWALDER, MD, senior resident in haematology

PIERRE CORNU, MD, senior resident in haematology (present address : Hôpital de la Providence, Vevey, Switzerland)

DONATELLA RUGGERO, MD, research fellow (present address: division of haematology, University Hospital, Bologna, Italy)

Blood Bank, Kantonsspital, University of Basle, Switzerland HANS PETER BURRI, MD, head

Division of Transplantation Immunology, Hôpital Cantonal, Geneva, Switzerland

MICHAEL JEANNET, MD, assistant professor patients $(44 \%)$ survived. In the two other groups, 22 patients survived $(69 \%)$, of whom 20 were completely self-sustaining $(63 \%)$. Engraftment and graft-versushost disease did not occur in the group who received antilymphocyte globulin and haploidentical marrow, and the haematopoietic reconstitutions in these patients were all autologous.

These results confirm the efficacy of antilymphocyte globulin in the treatment of severe aplastic anaemia and show that such treatment is at least as good as bonemarrow transplantation. Its mechanism of action remains unknown, but most patients with aplastic anaemia have a pool of haematopoietic stem cells able to repopulate the marrow after this type of treatment.

\section{Introduction}

The potential usefulness of antilymphocyte globulin followed by allogeneic marrow infusion in treating aplastic anaemia was first reported in $1970 .{ }^{1}$ In 1977 we reported the results in 29 patients with severe aplastic anaemia treated with antilymphocyte globulin with or without marrow infusion. ${ }^{2}$ The rationale ${ }^{3}$ and experimental ${ }^{4}$ and clinical $^{5}$ basis for this therapeutic approach to aplastic anaemia have been outlined. Despite these early results doubts remained about the usefulness of antilymphocyte globulin because of possible patient selection. We therefore began a study in 1976 to compare prospectively bonemarrow transplantation and treatment with antilymphocyte globulin alone or followed by bone-marrow infusion. All admitted patients with severe aplastic anaemia without exception were treated according to one protocol. They were classified 